F. Reprod. Fert. (1974) 36, 421-422

\title{
SURFACE ULTRASTRUCTURE OF THE RABBIT BLASTOCYST
}

\author{
S. BERGSTROOM AND GEGILIA LUTWAK-MANN
}

Department of Human Anatomy, Biomedical Center S-751 23 Uppsala, Sweden, and Unit of Reproductive Physiology and Biochemistry, Downing Street, Cambridge, England

(Received 20th August 1973)

Implantation of the blastocyst follows different patterns in different mammals. According to the relationship between trophoblast cells and uterine epithelium, a number of morphologically distinct types can be distinguished. These variations in the implantation process reflect differences in the properties of the cellular structures involved. Such differences, e.g. degree of invasion of trophoblast tissue, and type of intimacy between embryonic and maternal tissues, can be observed macroscopically. Some species differences in trophoblast differentiation and specialization can be observed under the light microscope (Steer, 1970; Hesseldahl, 1971; Bergström, 1972a), while others require electron microscopy (Enders \& Schlafke, 1969, 1971; Kirchner \& Seitz, 1972).

The degree of proximity between trophoblast and endometrium is reflected in the surface membranes (Bergström \& Nilsson, 1973), the structure of which may therefore serve as an indicator of that proximity. The cell surface may also express requirements of the cell in relation to its environment due to availability of nutrients or specific metabolic requirements (Follett \& Goldman, 1970; Bergström, 1972a). Surface ultrastructure can be studied conveniently by scanning electron microscopy (SEM) allowing surface screening without embedding and serial sectioning. The purpose of the present study was to compare some surface features in blastocysts from rabbits and some rodents by the use of SEM.

Blastocysts from rabbits on Days 5 and 6 of pregnancy were recovered by gently opening up the uterine horns with a fine knife and rapidly transferring the blastocysts on a steel spoon to glutaraldehyde $(2.5 \%$ in Soerensen's phosphate buffer). After rinsing in buffer, postfixation was carried out in $1 \%$ osmium tetroxide in the same buffer. The blastocysts were washed three times in redistilled water before freezing in isopentane cooled by liquid nitrogen. Freeze-drying was carried out at $-79^{\circ} \mathrm{C}$ and all specimens were subsequently coated with carbon and gold-palladium before examination in a JEOL JSM-U3 scanning electron microscope.

The blastocysts were often cracked in the freezing process owing to the relatively large volume of blastocoelic fluid in this species. This damage occurred particularly in the zona pellucida, which displayed the same tendency to crystallization artifacts as the mouse zona (Bergström, 1972b, 1973). In zonal areas free of crystallization artifacts, the surface structure was smooth (Pl. 1, Figs 1 and 2) and similar to that observed in the mouse (Bergström, 1972b). 
The trophoblast cells had a polygonal appearance though individual cells varied much in shape and size. In zona-encased blastocysts in which the trophoblast cells were visible through a zonal crack, the cells had few microvilli (Pl. 1, Fig. 2). Zona-free blastocysts showed a conspicuous lining of microvilli, mostly concentrated to the peripheral parts of each cell surface, though some cells displayed an even dissemination of microvilli (Pl. 1, Figs. 3 to 5).

The microvilli were fairly long (length 2.0 to $2.5 \mu \mathrm{m}$; diameter 0.15 to $0.20 \mu \mathrm{m}$ ), thereby differing from those of mouse and rat blastocysts (Bergström, Lundkvist \& Naeslund, 1974). The difference in number of microvilli in zonaencased and zona-free blastocysts may denote an increase in metabolically functional cell surface area, a phenomenon that also coincides with the preimplantation stage in the mouse blastocyst (Bergström, 1972a).

\section{REFERENGES}

Bergström, S. (1972a) Scanning electron microscopy of ovoimplantation. Arch. Gynäk. 212, 285.

BERGSTRöm, S. (1972b) Shedding of the zona pellucida in normal pregnancy and in various hormonal states in the mouse. A scanning electron microscope study. Z. Anat. EntwGesch. 136, 143.

Bergström, S. (1973) Preparation of ova for scanning electron microscopy. Uppsala 7. med. Sci. 78, 1.

Bergström, S., Lundkvist, Ö. \& NAesLund, G. (1974) Blastocyst development in vitro and in vivo. In: Scanning Electron Microscopy Atlas of Mammalian Reproduction, Ed. E. S. E. Hafez. In press.

Bergström, S. \& NiLsson, O. (1973) Various types of embryo-endometrial contacts during delay of implantation in the mouse. 7. Reprod. Fert. 32, 531.

Enders, A. \& SGHLAFKe, S. (1969) Cytological aspects of trophoblast-uterine interaction in early implantation. Am. 7. Anat. 125, 1.

Enders, A. \& Schlafke, S. (1971) Penetration of the uterine epithelium during implantation in the rabbit. Am. F. Anat. 132, 219.

Follett, E. A. G. \& Goldman, R. D. (1970) The occurrence of microvilli during spreading and growth of BHK 21/C 13 fibroblasts. Expl Cell Res. 59, 124.

HesseldaHL, H. (1971) Ultrastructure of early cleavage stages and preimplantation in the rabbit. $Z$. Anat. EntwGesch. 135, 139.

KIRCHNER, C. \& SEITZ, K. A. (1972) Elektrönennirkroskopische Untersuchungen über die Blastozyste des Kaninchens vor der Implantation in bezung auf ihre wechselbezieliung zur Uterinen Umgebung. Wilh. Roux Archiv. 170, 221.

SteER, H. W. (1970) The trophoblastic knobs of the preimplanted rabbit blastocyst: a light and electron microscopic study. J. Anat. 107, 315.

\section{EXPLANATION OF PLATE 1}

Fig. 1. Rabbit blastocyst, recovered at 16.00 hours on Day 5 still encased in its zona pellucida. The blastocyst is broken and the inside of the blastocyst cavity with the individual trophoblast cells can be seen. The spongy layer in the deeper part of the cavity probably represents material precipitated from the blastocoelic fluid. $\times 35$.

Fic. 2. Rabbit blastocyst, recovered at 16.00 hours on Day 5. Parts of a cracked zona surround polygonal trophoblast cells. Note the smooth appearance of zona and few microvilli on the trophoblast cells. $\times 350$.

Fig. 3. Rabbit blastocyst, recovered at 16.00 hours on Day 6. Note the polygonal trophoblast cells with a conspicuous microvillous lining, mostly peripherally situated on each cell. $\times 750$.

Fig. 4. Detail of Fig. 3 showing areas with high density of microvilli along trophoblast cell borders. $\times 2250$.

Fig. 5. Detail of Fig. 4 showing microvilli immediately adjacent to an intercellular junction. Note long and slender microvilli. $\times 8500$. 
PLATE 1

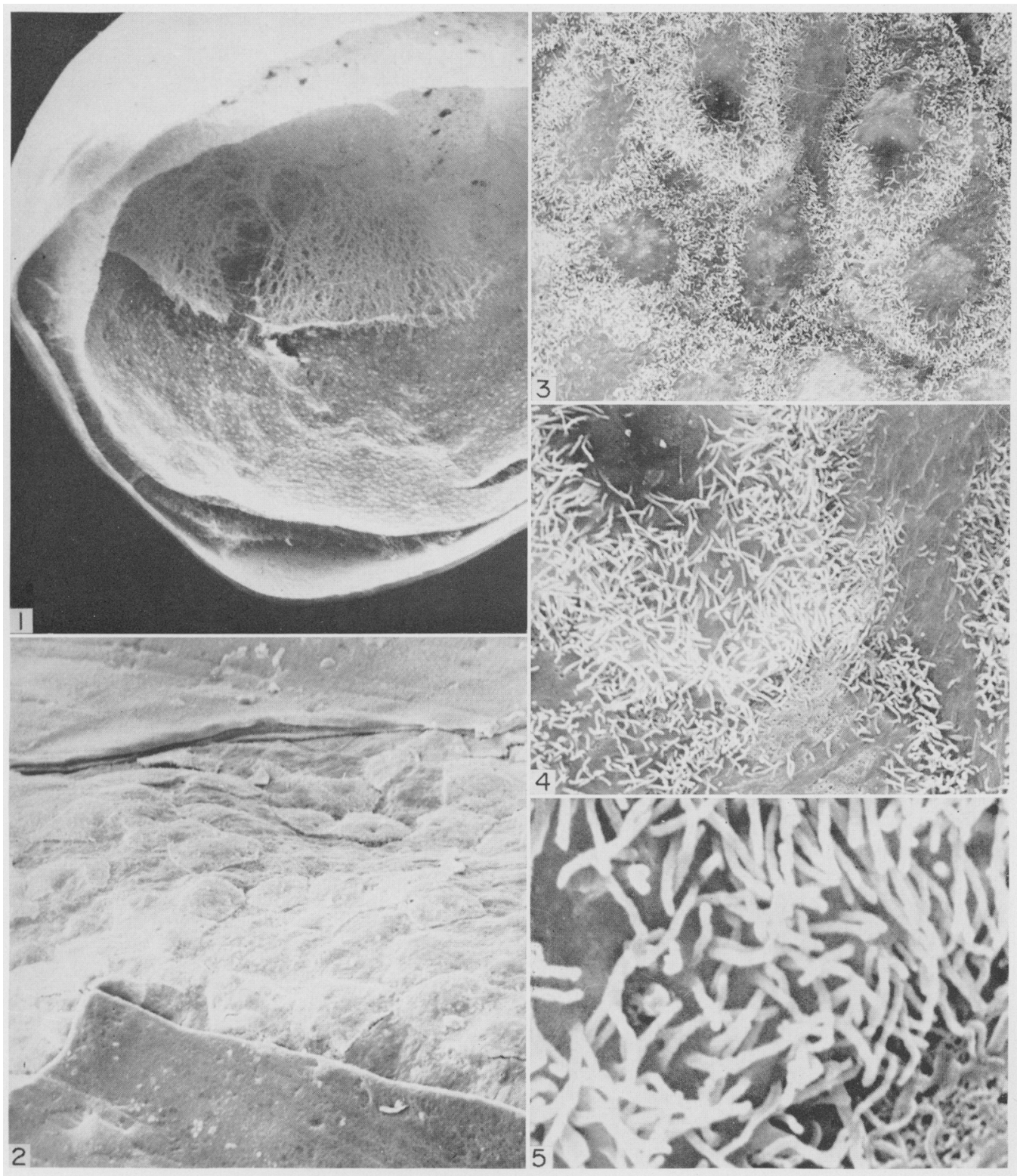

(Facing p. 422) 